\title{
Teaching theology from a distance: Experiences of the Institute of Distance Learning at St Tikhon's Orthodox University in Moscow, Russia
}

\begin{tabular}{|c|c|}
\hline \multicolumn{2}{|c|}{$\begin{array}{l}\text { Authors: } \\
\text { Gennady Egorov }^{1} \text { (D) } \\
\text { Tatiana V. Melanina }^{2} \text { (D) } \\
\text { Jennifer J. Roberts }^{3} \text { (D) }\end{array}$} \\
\hline \multicolumn{2}{|c|}{$\begin{array}{l}\text { Affiliations: } \\
{ }^{1} \text { Institute of Distance } \\
\text { Learning, St Tikhon's } \\
\text { Orthodox University, } \\
\text { Moscow, Russia }\end{array}$} \\
\hline \multicolumn{2}{|c|}{$\begin{array}{l}\text { ²Department of New } \\
\text { Technologies in Humanitarian } \\
\text { Education, Institute for } \\
\text { Distance Learning, } \\
\text { St Tikhon's Orthodox } \\
\text { University, Moscow, Russia }\end{array}$} \\
\hline \multicolumn{2}{|c|}{$\begin{array}{l}{ }^{3} \text { Institute for Open and } \\
\text { Distance Learning (IODL), } \\
\text { University of South Africa, } \\
\text { Pretoria, South Africa }\end{array}$} \\
\hline \multicolumn{2}{|c|}{$\begin{array}{l}\text { Corresponding author: } \\
\text { Jennifer Roberts, } \\
\text { buckjj@unisa.ac.za }\end{array}$} \\
\hline \multicolumn{2}{|c|}{$\begin{array}{l}\text { Dates: } \\
\text { Received: } 30 \text { Nov. } 2018 \\
\text { Accepted: } 01 \text { Aug. } 2019 \\
\text { Published: } 21 \text { Nov. } 2019\end{array}$} \\
\hline \multicolumn{2}{|c|}{$\begin{array}{l}\text { How to cite this article: } \\
\text { Egorov, G., Melanina, T.V. \& } \\
\text { Roberts, J.J., 2019, 'Teaching } \\
\text { theology from a distance: } \\
\text { Experiences of the Institute } \\
\text { of Distance Learning at St } \\
\text { Tikhon's Orthodox University } \\
\text { in Moscow, Russia', HTS } \\
\text { Teologiese Studies/ } \\
\text { Theological Studies 75(1), } \\
\text { a5343. https://doi.org/ } \\
\text { 10.4102/hts.v75i1.5343 }\end{array}$} \\
\hline \multicolumn{2}{|c|}{$\begin{array}{l}\text { Copyright: } \\
\text { (C) 2019. The Authors. } \\
\text { Licensee: AOSIS. This work } \\
\text { is licensed under the } \\
\text { Creative Commons } \\
\text { Attribution License. }\end{array}$} \\
\hline \multicolumn{2}{|l|}{ Read online: } \\
\hline 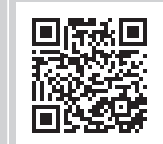 & $\begin{array}{l}\text { Scan this QR } \\
\text { code with your } \\
\text { smart phone or } \\
\text { mobile device } \\
\text { to read online. }\end{array}$ \\
\hline
\end{tabular}

This article considers the basic problem of online education owing to the lack of direct contact between all participants in the study process. The experience of distance theological education in Russia as a whole and the personal experience of two of the authors who are lecturers at St Tikhon's Orthodox University in Moscow are used to understand and describe the methods of addressing the challenge of direct communication. Based on 15 years of experience of two of the authors (Egorov and Malanina) in the field of distance theological education in Russia, as well as survey results on preferences for communication in theological distance education training, the article presents research results that confirm the preference for the way the current study process is organised based on different communicative activities for various levels of learning. The authors also report on the existing, and actively used, teaching staff training system on theological distance education. The results are presented in the form of a pyramid as a framework for theological distance education in a Russian context.

Keywords: Communication; Distance Education; Russia; Theological education; Staff training.

\section{Introduction and theoretical framework}

Distance Learning (DL) projects for training both priests and laymen appeared in Russia from the end of 2003 to the beginning of 2004. Further development showed that while DL related to theological training programmes is restricted (available only to seminary students, which seems reasonable), the programmes for lay people were divided into two groups. One group included orthodox educational projects, while the other included programmes aimed at systematic longterm and short-term DL. The first group includes several well-known web portals, where orthodox literature is available for a variety of purposes - from liturgical books to fiction. In addition, there are calendars with life stories of the saints and readings from the Holy Scriptures, applications that offer daily quotes of wisdom, multimedia materials, as well as self-control tests and an opportunity to ask a question to a priest or a moderator. These projects can provide the required large-scale involvement and accessibility, but they cannot be likened to educational ones because traditional education - and especially theological education - involves interaction between a teaching instructor and learners. Delamarter $(2005)$ and Heinemann $(2006,2007)$ suggest that face-to-face residential education is considered as the standard of excellence for theological education. Palka (2004) supports this and states that formational learning best occurs in an on-campus context.

Hockridge (2013) asserts that concerns about the suitability of Distance Education (DE), and particularly online DE, is twofold: whether face-to-face interaction is a necessary part of formational learning and whether web-based technologies can provide a tool for genuine social interaction. There is an ongoing debate in theological circles around these points, which is supported by Lowe and Lowe (2010:85) who state that '[p]rofound disagreements exist among theological educators regarding the wisdom of delivering theological education at a distance, apart from the salient attributes of a campus community'.

At the beginning of the 20th century, only people who were training to become priests could enrol for studies in theology in Russia. In 1990, the university was established to train lay people as well as priests, and in 2004, St Tikhon's received university status.

St Tikhon's developed a short-term one-semester catechetical programme 'Foundations of Orthodoxy' and a long-term theological education programme - 'Theology', designed for several

Note: OEH: The Online Educated Human: Teaching values, ethics, morals, faith and religion at a distance, sub-edited Ignatius Gous (University of South Africa). 
years of training, which have been successfully implemented for 14 years and presented completely in a DL format. In addition, there are several short-term programmes for individual theological courses and the first graduation from the master's programme (MSc) in Theology, the course of study lasts 2.5 years, will soon occur.

The implementation of DL on the Internet more than 20 years ago was considered a promising means of replenishing an ever acute need for mass education, by eliminating some of the shortcomings of traditional, full-time on-campus education. Among these shortcomings are the lack of infrastructure, financial constraints, as well as a deficiency of qualified teaching staff capable of satisfying the requirements of all those wishing to qualify with a certain degree of education.

In 2016, the Russian Federation launched a project called 'Modern Digital Educational Environment' to provide opportunities for many more Russians to further their education. One of their targets was to train 11 million students through online courses and to develop 4000 such courses (Barinova 2017). However, despite the growth of emerging opportunities offered through online education, there has not been any radical breakthrough yet (Roshhina, Roshchin \& Rudakov 2018). None of the above obstacles has been significantly overcome, which still raises a question of their causes. Perhaps, they are rooted neither in economic, nor in technological aspects, but in the very nature of learning.

Theological DE is not an exception in this respect. An analysis of the development of DL theological curricula (Egorov \& Melanina 2014) has led to the conclusion that it makes sense to distinguish between two target audiences, namely, students of theological schools (future clergymen) and laymen who want to extend their theological background knowledge. Naidoo (2012) discusses the concept of formational learning in theology education, and particularly highlights the development of ministerial and spiritual maturity that is expected of church ministers. According to Overend (2008) and Percy (2010), theological education should encompass the training of the whole person, which includes spiritual and character formation - not just the transmission of theological content. Thus, the question being asked is whether formational training can take place in an online DE environment.

This article is based on the the Community of Inquiry Model', as put forward by Garrison, Anderson and Archer (2001), which links three presences to successful online learning - cognitive, social and teaching presences. It is the collaborative aspect of these three presences that result in students being able to achieve deep and meaningful learning.

Garrison (2009:352) defines social presence as 'the ability of the participants to identify with the community, communicate purposefully in a trusting environment and develop interpersonal relationships'. Anderson et al. (2001:5) see teaching presence as 'the design, facilitation and direction of social and cognitive processes for the purpose of realizing personally meaningful and educationally worthwhile learning outcomes'. Finally, Garrison et al. (2001:11) state the cognitive presence refers to 'the extent to which learners are able to construct and confirm meaning through sustained reflection and discourse'.

Computer-based discussion forums play a central role in the Community of Inquiry Framework; thus, the pedagogy behind online discussion forums assumes that students and teachers will work together, not independently, as in traditional DE (Swan \& Ice 2010).

Garrison (2015:27) states that 'as a result of the proliferation of modern communication technologies, Higher Education is no longer solely purposed to provide access to information to the students'. It needs to go much further and enable the learners to develop skills that empower them to critically assess the information that is presented to them.

Thus, the research question being asked is:

What methods of communication in DE theology training are best suited to both the subject and content specific requirements, as well as the formational training of theology students in Russia?

The objective of this article is, therefore, to describe the experiences of the leaders of the courses, the lecturers' evaluation of their training, as well student views on the methods of communication that best suit them. From these results, a distance teaching and learning model for the students is proposed in the conclusion of this article.

\section{Methodology}

The methodology for this article draws on a narrative, ethnographical review of the experiences of two lecturers at the St. Tikhon's Orthodox University, Moscow, Russia. St. Tikhon's Orthodox University is a theological university for the laity who are affiliated with the Russian Orthodox Church. Narrative inquiry is a way of understanding and inquiring into experience through 'collaboration between researcher and participants, over time, in a place or series of places, and in social interaction with milieus' (Clandinin \& Connelly 2000:20). It is a 'genre of analytic frames whereby researchers interpret stories that are told within the context of research and/or are shared in everyday life' (Allen 2017:1069). The role of the narrative in this article is to provide a background story and description of distance education theological teaching in the Russian context. In addition, this article also includes descriptive results from a quantitative survey conducted among students at the university. Additional results emanate from programme evaluation of lecturers who have completed a course on distance education teaching. The results are reported as a narrative from the two lecturers, as well as descriptive quantitative frequencies from a survey conducted among students from both a long-term programme as well as a short-term programme. In addition, feedback from the DL programme for lecturers was analysed to identify expressions (semantic units) in which the respondents 
described their experiences and provided an assessment of the course.

The population for the survey consisted of 131 students who were studying for the one-semester short course on the fundamentals of orthodoxy, and 182 students undertaking the long-term professional training programme on theology. A census survey was conducted, and all students were invited to complete the survey. A census study occurs if the whole population is either small or if there is a possibility for the entire population to be sampled. The sampling frame for this study used a complete list of all the members of the organisation, that is, all students in the course, and is thus considered to be a census study. The response rate for the one-semester course was 72\% (94 respondents) and for the long-term programme the response rate was $78 \%$ (142 respondents). The survey was conducted by means of an online questionnaire using the Learning Management System (LMS) Moodle, and participation was voluntary. A questionnaire using a five-point Likert scale was sent to all participants. The questions were related to the types and methods of communication between the students and the lecturers as well as the types of responses, time frame for responses, types of assessment communication, discussion forums and the use of emoticons. It also included a question related to the students' preferred method of teaching and communication - and this aspect is reported in this article. In addition, open-ended questions were asked and analysed.

In addition, results from an evaluation by teachers at the university, on their perceptions of the online training programme on teaching through $\mathrm{DE}$, are presented. The study involved all the teachers who successfully completed the online DE programme. Each participant wrote evaluation reviews directly after the end of the programme. For the period 2013-2018, 108 reviews were received. Feedback on the course was presented in free-form writing, but all respondents were asked to pay special attention to the following aspects, namely, general impressions of the course construction and the experience of training on it, errors in the design of the course, lack or excesses of content, shortcomings in assignments and discrepancy in the forms of activity. The feedback was analysed in order to identify expressions (semantic units) in which the respondents described their experience and gave an assessment. Then these expressions were combined according to the principle of similarity and the most frequently used ones are presented in the results section.

Drawing on all the empirical results of this study, a DE framework for teaching theology in Russia is proposed in the form of a programme pyramid in the conclusion of this article.

\section{Review of literature on teaching theology at a distance}

Rovai, Baker and Cox (2008) found in their study that on-campus teaching is important for formation and they questioned whether online DE can fulfil this role. Nichols (2015), however, carried out empirical research and ascertained that statistically there was little difference in the spiritual formation training between distance and on-campus students. In a further qualitative study, based on in-depth interview with theological DE students, Nichols (2016) confirmed these results. He concluded that both on-campus and DE students experienced similar transformative learning experiences.

Egarov and Melanina (the two lecturers who are presenting this ethnographic evidence) suggest that this interaction should be compulsory and, therefore, deliberately organised by the training institution, systemic and based on methodologically approved approaches. It is this aspect that has determined the emergence and relevance of distance theological education programmes, which we have attributed to the second group. St. Tikhon's Orthodox University is a pioneer in this field, as in 2004 it offered the first DL programme for lay people.

However, as it follows from numerous publications in Russia, the educational space of the future belongs to Massive Open Online Courses (MOOCs) (Barinova 2017; Gotskaya \& Zhuchkov 2016), where the training organisation is opposed to systematically designed curricula with the compulsory direct participation of a teaching instructor.

These MOOCs, according to many authors reflecting on this topic, will go a long way in solving the problem of the accessibility of education - including higher education - for anyone wishing to get it. This is in line with the Russian priority project as discussed in the previous paragraph. Some authors predict that the rapid growth of online courses predicts the potential obsolescence of traditional educational institutions.

The implementation of these courses does not require any buildings, classrooms, deans or departments.

Motivated Internet users can freely form their study trajectory, selecting the courses they need, which are designed and made available on the Internet, and teaching to a wide-range audience. The quality of the subjects taught is assessed by 'free voting of users'. At the same time, enthusiasts of open education assume that the trainees can build their own 'study trajectory'. Moreover, it is presented as one of the significant advantages over traditional higher education, namely, one needs to study only 'necessary' courses without wasting time on 'redundant' courses. A valid argument in favour of this standpoint is the notion that the rates of changes in the modern world are so great that no one can be considered an expert or a qualified teaching instructor.

All of the above-mentioned facts can be considered plausible. However, we also cannot but agree that not all areas of human activity can be represented in the field of mass education because of its specific nature. The main and 
intrinsic characteristic of MOOCs is the minimisation or even complete absence of direct individual contact of learners with a teaching instructor. Massive open online courses can be an excellent tool for mastering individual areas of knowledge, developing certain skills, expanding horizons, etc., but they cannot replace traditional education because education is something of a deeper and wider nature, something that is born only from the interaction of learners and teachers. This is especially the case in religious education where 'formation' is considered an essential component. Formation can be described as the development of character and spiritual maturity (Hockridge 2013).

Nichols (2011) refers to the distinction between akadmeia and ecclesia, and purports that online DE might be more suited to the academic community (akademeia) rather than the church community (ecclesia).

If in engineering training it is possible to minimise the communicative component with acceptable quality losses through controlling the correct learning outcomes produced by students (final or intermediate), this is not feasible in humanitarian education.

Humanitarian and theological knowledge belongs to the category of poorly formalised areas of education. A significant negative aspect is the absence of traditional, direct interaction of a teaching instructor with learners in the presentation and acquisition of the teaching content and the lack of immediate feedback, which is an intrinsic feature of full-time courses of study. Both these aspects are typical for any classroom activity and, more importantly, for out-of-audience communication. The importance of this factor in humanitarian education is conditioned by the need not only to inform the student of the teaching content and to ensure its acquisition and mastering but also to solve a problem of the interpretation of this content within the framework of authentic scientific and cultural practices.

Thus, compared with natural science subject areas, in DL of humanitarian and theological courses, the role of the communication component not only essentially increases but also becomes the leading one, and the very purpose of communication acquires a different nature, namely, a teaching instructor not only accompanies independent teaching of learners or controls their results. It is the task of the teaching instructor to adapt the study material to the personal characteristics of a particular learner, because the incomprehensible material always happens to be only individually incomprehensible. Challenging material should be taught and explained to students according to their personal characteristics, and an even more difficult task is to perceive and understand the material within a particular tradition. Bates (2015) supports this and asserts that the main limitation in teacher-student interaction is the time demands that are made on the teacher. As such, discussion forums are therefore not easily scalable.
In addition, in theological education, the possibility of group work plays an important role, both from the viewpoint of learning and solving problems associated with personal development. Therefore, the DL methodology applied in St. Tikhon's Orthodox University significantly differs from that used in MOOCs.

The core of the method of teaching used is as follows. The study material of a course is divided into semantic blocks, which are studied consistently by a group of students within a specific, predetermined period of time (a course schedule). For each block, a system of study tasks, both reproductive and creative, have been developed. In reproductive tasks, students are required to reproduce the key points of a block of the studied material. Reproduction can be made from memory (using automated testing or polling in a real-time mode) or using didactic tools (submitting individual answers to questions for the studied material or its summarising). In the latter case, it is not only quick checking of the submitted answer by the teaching instructor (within $24 \mathrm{~h}$ of the submission of answers by students) but also its addition or clarification by the learners, if necessary (answering additional questions of the teaching instructor).

Creative tasks are, as a rule, group activities, and they require joint solutions by students to problems within the framework of the studied material. The problem task is formulated by the teaching instructor and is offered for joint discussion in a discussion panel (forum) or chat format (if possible, a webinar). Problem tasks are formulated in such a way that in the course of group work, the learners can exhibit an understanding of the studied material and independently express their opinion about it. The level of its complexity and the competence of the learners determine the participation of the teaching instructor in the problem discussion.

The teaching instructor can moderate the discussion to achieve the learning outcomes, facilitate the understanding of the problem by individual participants, set a role model for discussion and opinion sharing within the framework of the studied material and illustrate (if necessary) the uncertainty and ambiguity of the offered solutions. As a rule, the discussion ends with summing up by the teaching instructor or one of the learners appointed by the teaching instructor. Certain types of creative tasks can be individual or mixed. For example, writing an essay on a given topic followed by a group discussion. In this case, the teaching instructor acts as an expert in the essay area and a moderator of the discussion. The assumption here is that these discussion forums are best handled in a face-to-face environment.

\section{Results}

The results are presented in three sections. Firstly, the narrative voice of the two lecturers concerned is presented in which they provide the background to distance education theological training in Russia and their reflections on the future use of online training. This has been presented in the background and the literature review section above contextualises 
the study. This is followed by the descriptive statistical results from the relevant question in the larger survey, that is, students' preferred method of teaching and communication. Finally, results are drawn from the lecturer course evaluation and experiences of the online DE course that they undertook.

The effectiveness of this training methodology is confirmed by the results of studies presented by two of the authors of this article at the eLearning Stakeholders and Researchers Summit 2017 conference held in Moscow, Russia, in the report 'Structure and characteristics of communication in distance learning' (Egorov \& Melanina 2017).

In the study mentioned above, in one of the questions, the respondents were asked to express their preference for the model of course designs, either active communication with the teaching instructor and groupmates or video lecture models supplemented with tests and a final course essay (similar to MOOCs ). This question from the study addresses the objective of this research, which is to obtain students' views on the methods of communication that best suit them.

Here we will only discuss the most significant conclusions regarding the relevance of communication in DE theological education. The options available for this particular question, regarding the preferred method of communication in the quantitative survey, were:

1. in favour of the existing model - full teacher involvement (face-to-face)

2. in favour of the model of MOOCs - no teacher involvement (MOOC)

3. a blended model, where the second model is supplemented by the first one

4. undecided.

The descriptive results of the questionnaire are presented in Figure 1.

As a result, the first and the third options (face-to-face and blended) were chosen, respectively, by $47 \%$ and $23 \%$ of the students of the short-term programme, 'Foundations of Orthodoxy'. Of the participants of the long-term programme, 'Theology', 52\% and 28\%, respectively, chose these options.

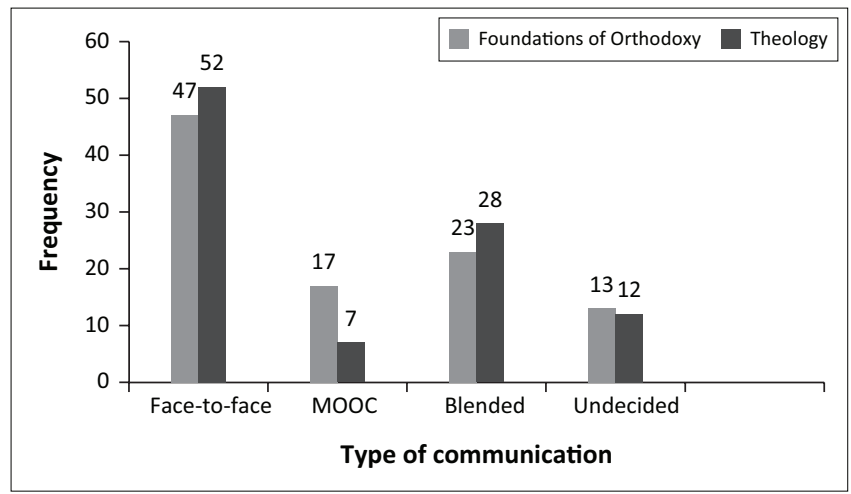

MOOC, Massive open online courses.

FIGURE 1: Frequency of choice of course presentation communication.
The second option of a MOOC (online) type of presentation was chosen by $17 \%$ and $7 \%$ of learners, respectively.

The results from Figure 1 indicate that the most popular choice of communication method is face-to-face, for students of both the short course on orthodoxy, as well as the longer course on theology, although slightly higher for the long-term students. Approximately, half the students prefer this method of communication. Around a quarter of the students are in favour of a blended approach, which is partly online and partly face-to-face.

When analysing the MOOC (online) option, it can be seen that very few 'Theology course' students $(7 \%)$ are in favour of online training. This figure increases with the 'Foundations of Orthodoxy' students where $17 \%$ prefer an online means of teaching and learning.

When analysing the responses, it should be considered that more than half of the students taking these courses live in Moscow, St. Petersburg or their environs. This means that if there is a choice of how to organise the study process, the distance format is more suitable for them than the full-time format, with preference being given to the communicative (face-to-face) model.

The most interesting are the reasons provided by respondents that prefer MOOCs (with no teacher involvement) instead of those courses offered in our university. In most cases, the respondents pointed out that video lectures with a minimum 'feedback' are less labour-intensive than the DL methodology used in St Tikhon's Orthodox University.

Most answers (52\% of the long-term 'Theology' course students) expressed a clear approval of the experienced training methodology, which deserves attention, despite what was said above about the method of selecting entrants. The reasons for this choice include the most frequent statement that the system of tasks performed under the guidance of the teaching instructor is the most effective method of learning, as it changes the worldview, positively affects the moral views, helps to go beyond the scope of available knowledge and broadens the horizon.

An important result of the analysis of open-ended questions was the confirmation of the educational effect of the deliberate organisation of interaction in a 'learner-learner' pair. Not less than a quarter of the respondents who advocated the DL methodology used in St Tikhon's Orthodox University spoke about the importance of intra-group communication on study issues for personal development. Their responses include the following components, namely, discussion skills, the ability to listen to someone else's opinion, expanding one's own outlook and looking at the problem through the analysis of groupmates' opinion, etc.

Obviously, this approach to the organisation of study interaction requires from the teaching instructor somewhat 
different skills and abilities than when working in a classroom or when designing MOOCs.

Therefore, an educational institution developing DL courses in the field of humanitarian knowledge should solve one of the central tasks of selecting and training teaching instructors, which includes the following aspects:

1. Provide opportunities to develop new types of study (learning) activities through the new types of activities offered for them to engage.

2. Allow to visualise the methodology of the DL process, technical capabilities of the system and their methodological applicability, without intentional emphasising of this teacher training aspect.

3. To give a teaching instructor an opportunity to assess the labour intensity, advantages and disadvantages of new activities, communication problems, etc.

A real example of a course, in the development and implementation of which an attempt has been made to solve the above-mentioned tasks, is a refresher course for university teachers. This course is called 'Theory and Methodology of Distance Learning' and was developed and implemented in St Tikhon's Orthodox University, along with the introduction of DL. The classes in this course are arranged in such a way as to enable teachers to participate as learners in all possible forms of study activities, both individual and group.

In addition, they assess the advantages and disadvantages both from the perspective of learners and teaching instructors (relying on the available experience of teaching), after which each participant is expected to design his or her own course and offer several classes from it in the system, acting as a teaching instructor.

This study involved all those who successfully completed the online DL programme. Reviews were written by each participant directly after the end of the programme. For the period from 2013 to 2018, 108 reviews were received. Feedback on the course was offered in free form, but all respondents were asked to pay special attention to such aspects as general impressions of the course construction and the experience of training on it; errors in the design of the course; lack or excesses of content; shortcomings in assignments; and discrepancy in the forms of activity. The feedback was analysed to identify expressions (semantic units) in which the respondents described their experience and gave an assessment. Then these expressions were combined according to the principle of similarity and the most frequently used ones were singled out.

Below is a selection of quotes from the feedback of teachers who have completed the course on learning outcomes:

'I discovered distance learning for myself' - a change in the whole concept of the opportunities offered by distance educational technologies in obtaining a fully-fledged education. (Semenov Sergey, Orenburg Seminary, Lecturer)

$[A] n$ incomparable advantage of distance learning as compared with traditional correspondence learning (the availability of materials for students, ease of their duplication for the teaching instructor - once published and then available for everyone, etc.). (George Orejkanov, Department of General and Russian Church History and Canon Law, Professor)

$[A]$ wide range of tools available for the teaching instructor to organize different types of study activities for the learners. (Dmitry Andrianov, Yarodlavl Seminary, Lecturer)

$[A] n$ unexpected outcome - the advantage of written communication through distance learning tools ('not every student is ready to ask a teacher a burning or nagging question, there is not always enough time for serious [or at least, attentive] discussion in the classroom or during the breaks'). (Dmitry Andrianov, Yaaroslavl Seminary, Lecturer)

[T] he course has offered a different look at traditional (full-time) study activities, revealed new opportunities for teaching in a classroom and organizing independent work of learners. (Mumrikova Larisa, PSTGU, Department of Pedagogy and Methods of Primary Education, Senior Lecturer)

As the long-term practice of the implementation of this course shows, it allows not only to solve the above-mentioned tasks but also to reveal the pedagogical motivation of the learners, and their ability and readiness to work in a setting of distance interaction. Designing and implementing their own training course in a DL format involving real learners allows the university administration to assess in advance the level of readiness of a future teaching instructor for communication with learners, the flexibility of methodical thinking and the mastery of the study process 'technology'.

\section{Conclusion}

Summarising all that has been discussed above, the authors arrived at the following conclusions:

1. There is a constant need for theological education. There is an obvious shortage of resources in Russia for obtaining it, including competent teaching staff. For most people, DL is the only possible way to satisfy this need. And this is true not only for residents of remote or sparsely populated areas but also for residents of metropolitan areas, who - if given a choice - prefer to study in a distance format.

2. Today, the desire for completely replacing formalised systematic education under the guidance of a teacher with public open courses in theological education is not proving to be efficient, because it is in this part of human experience that individual transfer of knowledge from one person to another is especially important. In the study of theology, the main emphasis is placed not only on obtaining information but also on the development of certain skills that need to be developed through formational learning. The essence of the study of theology is the operation of meaning, information and skills contained in them and opened by them. The fact is that the transmitted information and skills are in many ways symbols, and therefore evidence of something other than what they portray. Therefore, MOOCs are able to meet the human need for theological education only in part and should be supplemented with a possibility of studying under the 
guidance of experienced teaching instructors and in a team of like-minded people. An alternative is to follow the suggestion of Nichols (2016) that formational training can take place in a church community environment that is outside the formal university course.

3. Therefore, to achieve this goal, theological DE should include schemes (methods) that ensure a systematic two-way communication between the teaching instructor and students, as well as among the students themselves, in the field of the covered theological subject. This is confirmed by the social and teaching presences that were depicted in the Community of Inquiry model that was presented earlier.

Study activities should be constructed by the programme designers and carried out under the guidance of the teaching instructor in active interaction, initiated by both the teaching instructor and the learners. It is possible to carry out these interactions in both a face-to-face and an online environment, as confirmed by Nichols (2016).

4. The central problem of development and implementation of theological DE is the training of teaching instructors. A teacher of theology, working in a DL format, must comply with special requirements to establish personal contact with the students in conditions of distantly mediated interaction. It is important that this contact should be carried out mainly and first in a field of the taught subject, within the limits of study tasks.

5. In this case, a system of theological DE could be in the form of a pyramid based on MOOCs available for a large number of learners (see Figure 2). The middle part of this pyramid should be composed of less massive, but subjectoriented, courses provided by system designers with minimal teacher's involvement. On the top of the middle part, there should be more extensive, multidisciplinary

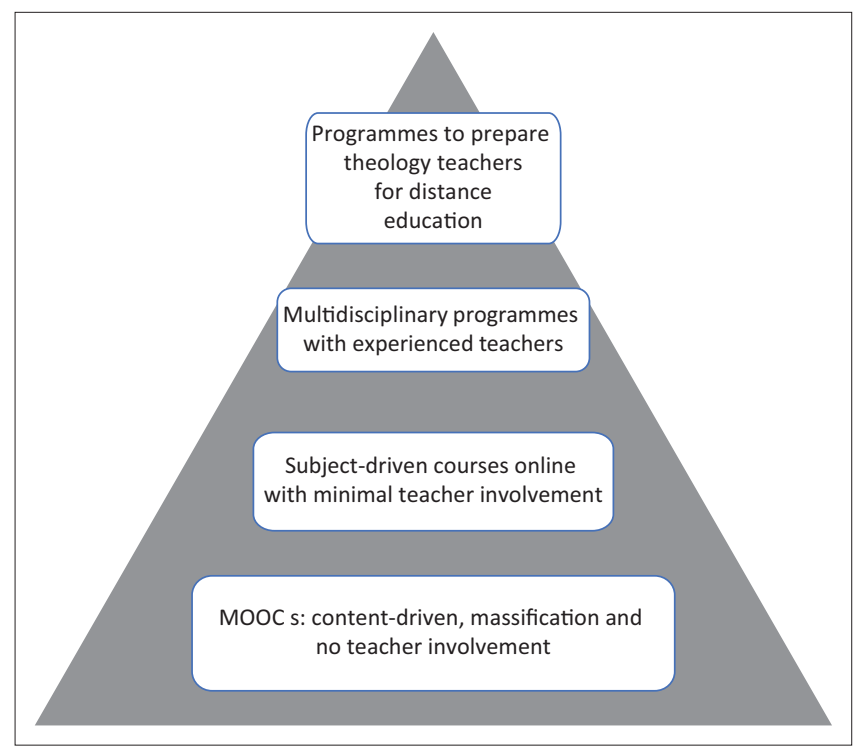

MOOC, Massive open online courses.

FIGURE 2: Pyramid of framework for distance teaching of theology in Russia. programmes that are mastered through the participation, and under the guidance, of experienced teaching instructors. These programmes cannot be as massive as those that lie below them in the described pyramid, but, as the authors' experience shows, as supported by a wellestablished methodical and administrative system, they are also able to provide a relatively greater coverage for those wishing to obtain a certain level of education, compared with full-time or part-time training. Finally, programmes capable of preparing future teaching instructors of theology, including DL programmes of different levels, and those able to design such programmes, form the upper part of the pyramid. The said pyramid is presented in Figure 2.

This pyramid model (Figure 2) is based on the results that were obtained from research carried out at St Tikhon's Orthodox University in Moscow, Russia. It combines results from students' questionnaires on preferred communication types, programme evaluation of teachers who undertook an online course on DE, as well as the narratives of two lecturers. Online training has been identified as the way forward for teaching in Russia because of the large number of students that can be educated and its cost-effectiveness. However, in theological training, the preferred method is still face-to-face approach or a blended approach. This pyramid takes all these factors into account and proposes the MOOC format for aspects of training that are contentbased, and then moves up the pyramid with more teacher involvement, particularly for preparing teachers and instructors in DE theology teaching. It is recommended that the model should be tested in other countries, as well as different contexts of DE theology training.

\section{Acknowledgements Competing interests}

The authors declared no potential conflicts of interest with respect to the research, authorship and/or publication of this article. One of the authors is a co-editor of the special edition of this journal. The decision to include this article was taken solely by the second co-editor, based on reviewer reports.

\section{Authors' contributions}

G.E. wrote the first draft of the article based on his experiences at St Tikhon's University and provided the methodology. T.V.M. carried out empirical data collection and analysis. J.J.R. provided conceptual framework, literature review and rewrote the article in English from its Russian version.

\section{Ethical considerations}

This article followed all ethical standards for a research without direct contact with human or animal subjects. 


\section{Funding information}

This research received no specific grant from any funding agency in the public, commercial, or not-for-profit sectors.

\section{Data availability statement}

Data sharing is not applicable to this article as no new data were created or analysed in this study.

\section{Disclaimer}

The views and opinions expressed in this article are those of the authors and do not necessarily reflect the official policy or position of any affiliated agency of the authors.

\section{References}

Allen, M. (ed.), 2017, The SAGE encyclopedia of communication research methods, viewed 23 March 2019, from https://methods.sagepub.com/reference/the-sageencyclopedia-of-communication-research-methods/i9374.xml

Anderson, T., Rourke, L., Garrison, D.R. \& Archer, W., 2001, 'Assessing teaching presence in a computer conferencing context', Journal of Asynchronous Learning Networks 5(2), 1-17. http://dx.doi.org/10.24059/olj.v5i2.1875

Barinova, N.V., 2017, 'Problemy razvitya distancionnogo i electronnogo obrazovaniya $v$ Rossii [Problems of development of remote and electronic education in Russia]', IT Portal, viewed 03 February 2018, from https://itportal.ru/science/tech/ problemy-razvitiya-distantsionnogo-/

Bates, A.W., 2015, Teaching in a digital age: Guidelines for designing teaching and learning, viewed 22 July 2018, from https://opentextbc.ca/teachinginadigitalage/

Clandinin, D. \& Connolley, F., 2000, Narrative Inquiry: experience and story in qualitative research, Jossey Bass publishers, San Francisco, CA.

Delamarter, S., 2005, 'Theological educators and their concerns about technology', Teaching Theology and Religion 8(3), 131-143. https://doi.org/10.1111/j.14679647.2005.00237.x

Egorov, G. \& Melanina, T.V., 2014, 'Bogosloviye na rasstoyanii. Pravoslavnoye distantsionnoye obrazovaniye: Desyat' let spustya [Distance approach to theology. Orthodox distance education: Now and ten years ago]', Zhurnal Moskovskoy Patriarkhii 8(8), 86-89.

Egorov, G. \& Melanina, T.V., 2017, 'Struktura i kharakteristiki kommunikatsii v distantsionnom obrazovanii (institutsional'noye issledovaniye) [Structure and characteristics of communication in distance learning (institutional research)]', in International conference 'elearning stakeholders and researchers summit' 2018, viewed 21 August 2018, from https://estars.hse.ru/mirror/pubs/share/211451594.
Garrison, D.R., Anderson, T. \& Archer, W., 2001, 'Critical thinking, cognitive presence, and computer conferencing in distance education', American Journal of Distance Education 15(1), 7-23.

Garrison, R., 2009, 'Implications of online and blended learning for the conceptual development and practice of distance education', The Journal of Distance Education 23(2), 93-104.

Garrison, R., 2015, Thinking collaboratively: Learning in a community of inquiry, Routledge, New York, NY.

Gotskaya, I.B. \& Zhuchkov, V.M., 2016, 'Current state, problems and prospects of development of massive open online courses', Prepodavatel XXI vek 4(1), 117-127.

Heinemann, M.H., 2006, 'Teacher-student interaction and learning in on-line theological education. Part III: Methodological approach', Christian Higher Education 5(2), 161-182. https://doi.org/10.1080/15363750500182828

Heinemann, M.H., 2007, 'Part IV: "Findings and conclusion"', Christian Higher Education 6(3), 185-206. https://doi.org/10.1080/15363750701283599

Hockridge, D., 2013, 'For educators using distance and online education to prepare students for relational professions', Distance Education 34(2), 142-160. https:// doi.org/10.1080/01587919.2013.793640

Lowe, S. \& Lowe, M., 2010, 'Spiritual formation in theological distance education: An ecosystems model', Christian Education Journal 7(1), 85-102. https://doi. org/10.1177/073989131000700106

Naidoo, M., 2012, 'Ministerial formation of theological students through distance education', HTS Teologiese Studies/Theological Studies 68(2), Art. \#1225, 8 pages. https://doi.org/10.4102/hts.v68i2.1225

Nichols, M., 2011, 'The Akademeia as paradigm for online community', Journal of Christian Education 54(1), 5-23. https://doi.org/10.1177/002196571105400102

Nichols, M., 2015, 'A comparison of the spiritual participation of on-campus and theological distance education students', Journal of Adult Theological Education 12(2), 121-136. https://doi.org/10.1179/1740714115Z.00000000041

Nichols, M., 2016, 'The formational experiences of on-campus and theological distance education students', Journal of Adult Theological Education 13(1), 18-32. https://doi.org/10.1080/17407141.2016.1158495

Overend, P., 2007, 'Education or formation: The issue of personhood in learning for ministry', Journal of Adult Theological Education 4(2), 133-148. https://doi. org/10.1558/jate2007v4i2.133

Palka, J., 2004, 'Defining a theological education community', International Review of Research in Open \& Distance Learning 5(3), 471-489. viewed 17 January 2018, from https://www.irrodl.org/index.php/irrodl/article/view/197/279.

Percy, M., 2010, Shaping the church: The promise of implicit theology, Ashgate, Burlington, VT.

Roshhina, J., Roshchin, S. \& Rudakov, V., 2018, 'The demand for massive open online courses (MOOC): Evidence from Russian education', Educational Studies (Moscow) 1(1), 174-199. https://doi.org/10.17323/1814-9545-2018-1-174-199

Rovai, A.P., Baker, J.D. \& Cox, W.F., 2008, 'How Christianly is Christian distance higher education?', Christian Higher Education 7(1), 1-22. https://doi.org/10.1080/ 15363750701285941

Swan, K. \& Ice, P., 2010, 'The community of inquiry framework ten years later', Internet and Higher Education 13(1-2), 1-4. https://doi.org/10.1016/j.iheduc.2009. 11.003 